\title{
On the bathymetric and latitudinal distributions of Coelorinchus cf. cookianus (Gadiformes: Macrouridae): first record documented with a remotely operated vehicle (ROV) in interior waters of the Campana Archipelago in central Patagonia, Chile (48 ${ }^{\circ}$ )
}

Sobre las distribuciones batimétricas y latitudinales de Coelorinchus cf. cookianus

(Gadiformes: Macrouridae): primer registro documentado con un vehículo operado remotamente (ROV) en aguas interiores del Archipiélago Campana en la Patagonia central, Chile (48 S)

Matthias Gorny ${ }^{1}$ \& German Zapata-Hernández², 3

\begin{abstract}
This is the first report of Coelorinchus cf. cookianus in comparable shallow coastal waters in the southeastern Pacific. Two individuals were filmed with a remotely operated vehicle (ROV) at $150 \mathrm{~m}$ of depth at the pacific entrance of the October Channel in the Campana Archipelago in central Patagonia, Chile. The specimens were identified on a video transect as macrourids by their elongate tapering tail, and the dorsal fins with two spinous rays. The fishes showed a series of regular dark saddle-like bands on the top and sides of the body from before the first dorsal fin to tip of tail. These criteria fit best with description of Coelorinchus cookianus which is described as endemic in New Zealand waters. However, two of four Coelorinchus species registered in the southeastern Pacific have widespread distributions in the southern hemisphere. Lack of sampling effort in the central Patagonian coast, including shelf and upper slope may explain why until now $C$. cookianus was exclusively reported in New Zealand waters.
\end{abstract}

\section{Key Words:}

Chilean channels and fjords, southeastern Pacific Ocean, continental shelf, Katalalixar National Reserve.

\section{Resumen}

Este trabajo es el primer reporte de Coelorinchus cf. cookianus en aguas costeras someras en el Océano Pacifico Suroriental. Dos individuos fueron filmados con un vehículo operado remotamente (ROV) a $150 \mathrm{~m}$ de profundidad en la entrada del Canal Octubre, en el Archipiélago Campana, Patagonia central, Chile. Los especímenes fueron identificados sobre un transecto de video como macrouridos por su cola alargada y aguzada, y la primera aleta dorsal con dos rayos espinosos. Los peces mostraron una serie de bandas oscuras regulares en forma de silla de montar en la parte superior y en los lados del cuerpo, desde antes de la primera aleta dorsal hasta la punta de la cola. Estos criterios se ajustan bien con la descripción de Coelorinchus cookianus que es descrito como endémico de las aguas de Nueva Zelanda. Sin embargo, dos de las cuatro especies de Coelorinchus registradas en el Pacifico Suroriental tienen una amplia distribución en el hemisferio sur. La falta de esfuerzo de muestreo en las costas de la Patagonia central, incluyendo la plataforma continental y el talud superior podrían explicar porque hasta ahora $C$. cookianus ha sido reportado exclusivamente en aguas de Nueva Zelanda.

\section{Palabras clave:}

Canales y fiordos Chilenos, Océano Pacifico Suroriental, Plataforma continental, Reserva Nacional Katalalixar.

Oceana Chile

$>$ mgorny@oceana.org

2 Doctorado en Biología y Ecología Aplicada (BEA), Universidad Católica del Norte, Coquimbo, Chile.

3 Nucleo Milenio de Ecología y Manejo Sustentable de Islas Oceánicas (ESMOI). 


\section{INTRODUCTION}

The family Macrouridae comprise 405 species and 36 genera of fishes and the genus Coelorinchus with 122 species is the most specious genus of this family (Iwamoto, 1978; Priede, 2017; Eschmayer et al. 2018) and 82 species are endemic of the Pacific Ocean (Priede, 2017). Macrourids are distributed mainly in deep water from the Arctic to Antarctic between $200 \mathrm{~m}$ and $2000 \mathrm{~m}$ depth (Cohen et al. 1990) and commonly inhabit continental shelfs, slopes, seamounts and mid-ocean ridges systems (Priede, 2017). The macrourids are characterized by a tail which tapers to a sharp point, giving them the common names of rattails or whip tails. Most of them have a light organ underneath the skin along the midline of the abdomen with opening just before the anus. Typical prey of these benthopelagic fishes are small crustaceans, polychaetes and myctophids (Cohen et al. 1990). So far, six Coelorinchus species have been reported from the southeast Pacific (Iwamoto, 1979), and three species from Chile including Coelorinchus aconcagua, C. chilensis and C. fasciatus (Iwamoto, 1978; Reyes \& Hüne, 2010). In Chile all species have a wide range of distribution (Acuña et al. 2008; Reyes \& Hüne, 2012), with C. aconcagua distributed from the south of Arica

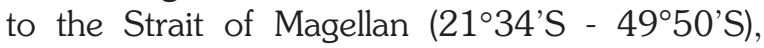
C. chilensis from Arica to Cape Horn $\left(18^{\circ} 40^{\prime} \mathrm{S}\right.$ - 55 $58^{\circ}$ 'S) and C. fasciatus between Valparaiso and the Strait of Magellan (33 $\left.03^{\circ} \mathrm{S}-53^{\circ} 53^{\prime} \mathrm{S}\right)$. However, C. chilensis is also reported from Peru and C. fasciatus from New Zealand and Africa (Iwamoto, 1978). Species of genus Coelorinchus appear as bycatch of commercial fisheries off coast in the north and south of Chile (Acuña et al. 2008; Reyes \& Hüne, 2012). Also, some specimens were caught over 130 years ago in the Messier channel, close to Wellington Island by the US trawler Albatross and next to the entrance of the Strait of Magellan during the Challenger expedition in 1875 (Iwamoto, 1978).

The Campana Archipelago at the western side of the Katalalixar National Reserve (KNR) represent one of the few places of the Chilean channels and fjords region that has not been explored by scientific expeditions. The archipelago is situated in central Patagonia, between the Penas Gulf and Castillo Channel ( $48^{\circ} \mathrm{S}-48^{\circ} 47^{\prime} \mathrm{S}$, Fig. 1a) in the western part of the KNR. The Campana Island is the largest island in this archipelago and is separated from the others smaller islands (Patricio Lynch and Cabrales Islands) by the October Channel (Fig. 1b). The seafloor of the western side of the archipelago is very shallow and covered by pinnacle-like steep raising rocks, emerging to the surface and preventing ships and boats to enter the October Channel from the Pacific Ocean. Access to the islands from the Castillo Channel is possible, but a very shallow narrow channel with a maximum depth of $2.5 \mathrm{~m}$ must be passed to get into the October Channel. The Campana Archipelago form part of a complex geography of channels and fjords of the Chilean Patagonia and is located less than $100 \mathrm{~km}$ east of the Southern Patagonian Icefield (SPI), which is still the largest ice mass on the southern hemisphere outside Antarctica. The dynamic regime of the SPI has shaped the adjacent west coast of central Patagonia by an important glaciomarine deposit set (Cassasa et al. 2002), resulting in comparable shallow channels filled with fine-grained sediments such as mud and clay towards the Pacific Ocean as observed during two expeditions in 1995 and 1996, which conducted sampling of benthos along the Messier Channel (Mutschke \& Gorny, 1999). Between 2009 and 2017 the NGO Oceana executed five expeditions to the KNR, being the Fallos Channel the eastern most part of the reserve which has been studied, taking biological samples of the benthos and doing underwater video footages by means of a remotely operated vehicle (ROV) (Gorny, Pers. Obs.). Visual documentation by means of ROV is an excellent alternative to investigate benthic communities at locations characterized by extremely irregular bottom structures as raising rocks that inhibit traditional bottom sampling with trawls or dredges and being inaccessible to non-technical divers (Gorny et al. 2018). Although images often do not allow exact taxonomic descriptions, within the past years the use of underwater video revealed numerous first records, including registers of new species of fishes and invertebrates from seamounts, oceanic islands and the continental coast of Chile (Friedlander et al. 2013; Easton et al. 2017; Gorny et al. 2018). 


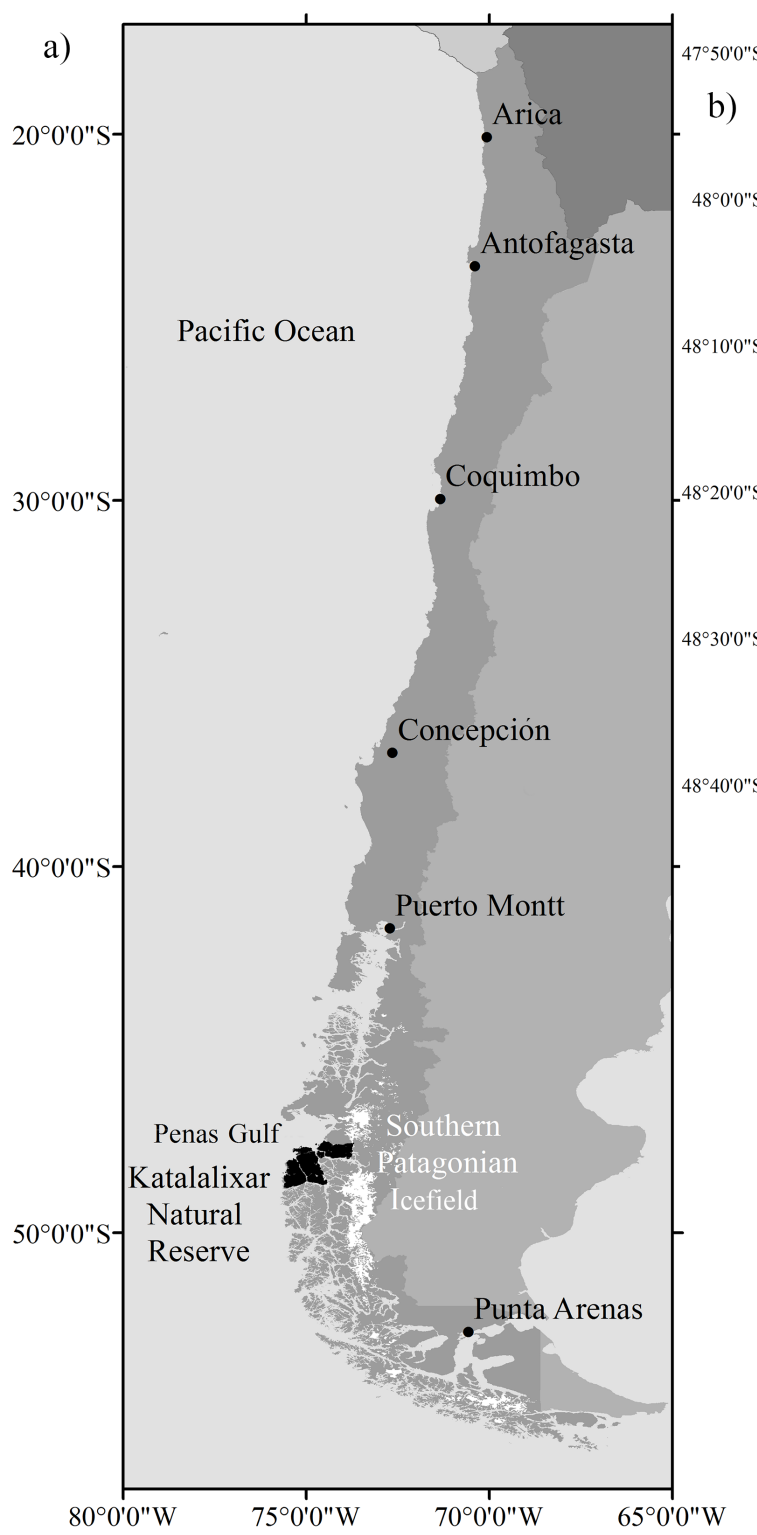

c)

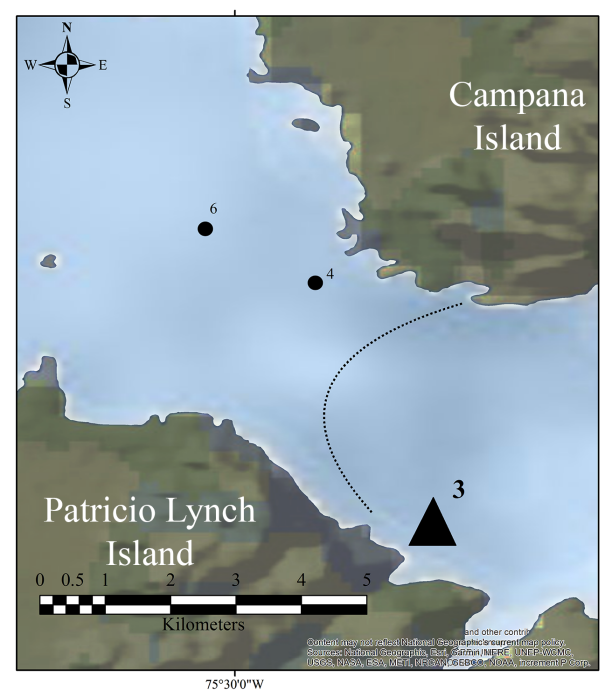

Fig.1. Map of the location where Coelorinchus cf. cookianus was filmed, indicating the location of the KNR in central Patagonia, next to the Southern Patagonian Icefield (a), the Campana archipelago with locations of all transects of underwater video with ROV during the expedition (b) and the enlarged view of the entrance of the October channel (c). The triangle indicates where the individuals of $C$. cf. cookianus were filmed, circles indicate all other transects without records of macrourid fishes and the dashed line shows the estimated location of the barrier at the entrance of the channel as measured with the eco sounder of the vessel. 
The general objective of the expedition to the interior waters of the Campana Archipelago, was to investigate the composition of benthic communities in the easternmost part of the KNR and to prove the hypothesis that species composition in the waters around the islands and next to the ocean differ in comparison to channels located much closer to the continent.

\section{MATERIAL AND METHODS}

During July 2018, the NGO Oceana and researchers of the University of Magallanes realized the "Katalalixar-II expedition" on board the motor vessel "Exploradores Patagonia II" to explore the Campana Archipelago. A ROV equipped with high definition video cameras was used to film the species composition of epibenthic communities on a total of 10 transects between the October Channel and Castillo Channel (48 $20^{\circ}$ 'S - 48 $45^{\prime} \mathrm{S} \& 75^{\circ} 20^{\prime} \mathrm{W}$ - $75^{\circ} 30 \mathrm{~W}$, Fig. 1b). The ROV (model Commander MK2 of Mariscope Meerestechnik, Kiel, Germany) was equipped with a front camera, recording in $2.7 \mathrm{k}$ (GoPro Hero4 set to $2704 \times 1524$ pixels, 60 frames per second), and a camcorder (Panasonic SD 909), recording 30 frames per second in $1920 \times 1080$ pixels, both positioned in front of the ROV with a fixed angle of 15 degrees towards the bottom. Four head lights of $200 \mathrm{~W}$ each were distributed in each corner of the ROV frame, and two laser pointers mounted with $10 \mathrm{~cm}$ of distance between each pointer above the cameras allowed to estimate the dimension of filmed objects. The distance between the cameras and the seafloor varied between $50 \mathrm{~cm}$ and one meter to avoid crashing the ROV against the seabed. The videos were reviewed using the open source cross-platform multimedia player VLC, version 3.0.3 from VideoLan (videolan.org), also allowing to extract digital frames of the observed species, which were refined with Adobe Photoshop version CC 2018 of the Adobe Company.

\section{RESULTS}

We report here the visual register of two macrourid fishes belonging to the genus Coelorinchus filmed with ROV during 30-min transect to $150 \mathrm{~m}$ depth (transect 3); the site was located next to the Pacific entrance of October Channel and about $200 \mathrm{~m}$ after a barrier of 40 $\mathrm{m}$ of depth at the channels mouth. The two individuals were filmed within a distance of about $10 \mathrm{~m}$ between them and on the same transect we also documented a comparable high abundance of myctophids, euphausids and squat lobsters Munida subrugosa. Both individuals of Coelorinchus were seen only from lateral and oblique view (Fig. 2a, b), and one specimen was $\sim 10 \mathrm{~cm}$ of length (Fig. $2 \mathrm{c})$, whereas the other one was much smaller. Both individuals may be considered as juveniles since adult rattails can reach up to $50 \mathrm{~cm}$ of total length (Bianchi et al. 1999).

According to Iwamoto (1978) members of the genus Coelorinchus can be distinguished from other macrourids by the remote position of the anus from the anal fin and the position of the black fossa of the light organ, visible only from a ventral view. However, the dimension of the first dorsal fin (height equal to postrostral length of head), the short blunt snout, and the back with dark saddles or bars extending slightly below the lateral line entail with descriptions given for species of the genus Coelorinchus distributed in the east Pacific and published by Iwamoto (1978). However, our specimens do not encompass exactly with descriptions given in the literature and we suggest that the visual register from the Campana Archipelago represent most probably a new species of the genus. A prominent dark spot as visible in the opercle of our larger specimen (Fig. 2d) is also described for Coelorinchus aconcagua (Iwamoto, 1978), but the back of that species does not show dark saddles as seen in both individuals from the archipelago (Fig. 2e). At least eleven of such saddles were visible in the larger fish from Campana Archipelago, whereas the smaller individual shows only four darker parts on the back, but in both specimens these saddles were clearly separated by pale oblique and vertical bands on the top and sides of the body and the ventral region was pale. The rattail $C$. fasciatus has darker saddles on the back, but not such vertical bands (Fig. 2f). We discard that our specimens were C. chilensis because that species is characterized by a head which is longer than wide, with a sharply pointed snout, and the trunk is without saddles or bands (Fig. 2f). 

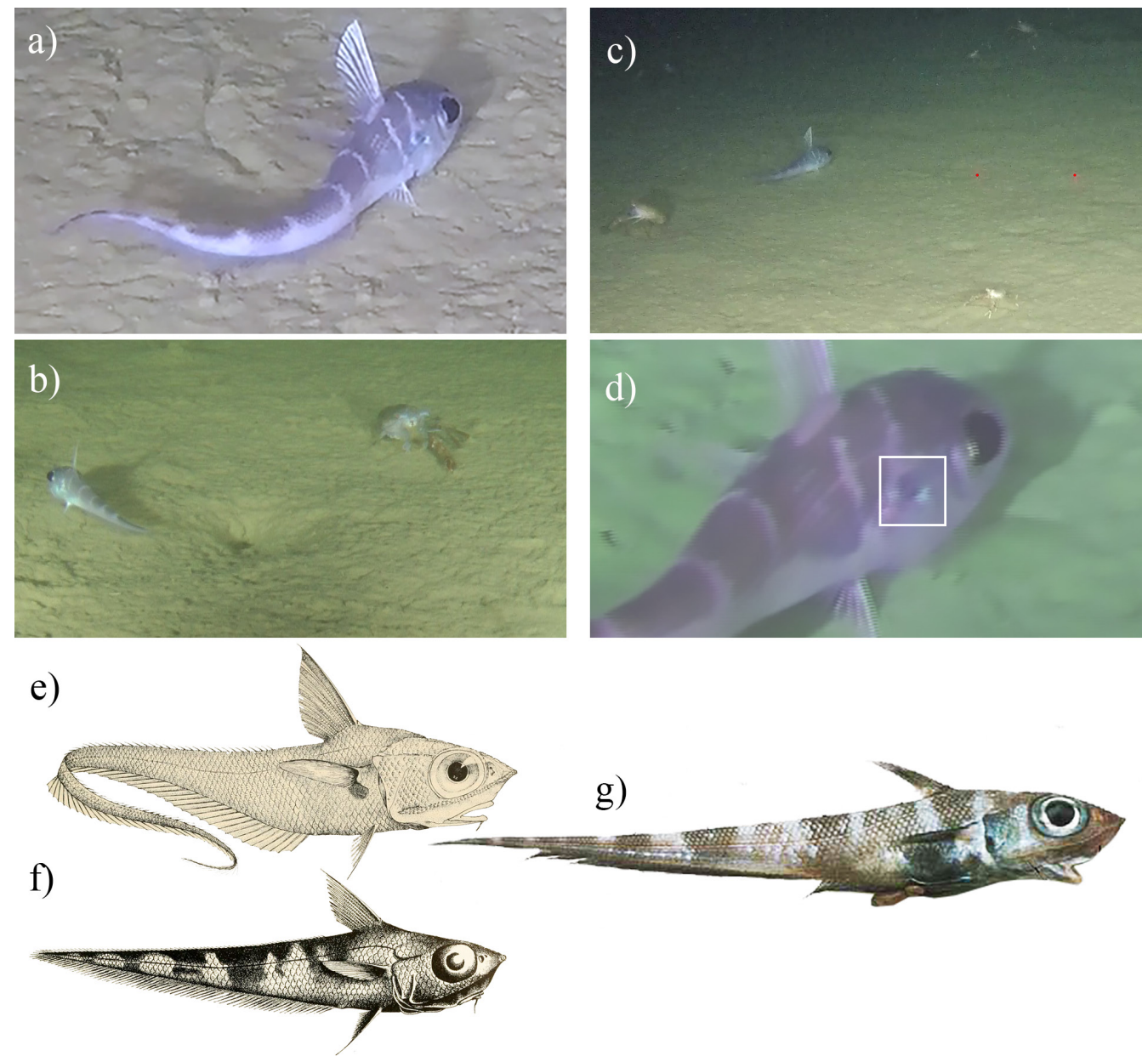

Fig. 2. Images of the two Coelorinchus cf. cookianus filmed at $150 \mathrm{~m}$ at the entrance of the October channel (a-d) and comparison with other species of the genus registered in Chile (e, f) and C. cookianus from New Zealand (g). The lateral view of both specimens shows at least 11 dark bands on the back of the larger fish (a), and four in the smaller individual (b). The large specimen was of about $10 \mathrm{~cm}$ of total length as indicated by the laser pointers of the ROV (c). A dark spot is clearly visible in the opercle and in the base of pectoral fin of the larger individual (a) and in the amplified view of the same fish (d). The crustaceans appearing on the images (a, b, c) were squad lobsters (Mundia subrugosa). The images below show C. aconcagua (e) and $C$. fasciatus (f), both redrawn from figure 10 and 11 of Iwamoto (1978). The dark spot at the base of the pectoral fin of the fish from our videos is the only criteria indicated as typical for $C$. aconcagua (e), which according to Iwamoto (1978) has a blueish to violet color of the trunk, but without any darker bands or saddles. However, all samples investigated by Iwamoto were preserved in alcohol. The fish at the right (g) corresponds to the species Coelorinchus cookianus, redrawn from images of the catalog of McMillan et al. (2011) which has pale bands and darker saddles similar to the specimens from the Campana archipelago.

\section{DISCUSSION}

The most similar species to our fishes according to the taxonomic descriptions and images is the cook's rattail C. cookianus described by McCann \& McKnight (1980). According McMillan et al. (2011) C. cookianus has a series of dark saddle-like bands on the top and sides of the body from before the first dorsal fin to tip of tail, no scales on underside of the snout and no enlarged or raised scales on the midline ahead of the first dorsal fin (Fig. 2g). Nevertheless, this species is considered as endemic of New Zealand waters (McMillan \& Paulin, 1993; McMillan et al. 2011). 
However, all six species of the genus which were reported for the southeast Pacific according to the review by Iwamoto (1978) cover wide longitudinal and latitudinal distribution ranges (Table 1). Iwamoto (1978) stated in his study that lack of samples may explain restricted geographical distribution patterns of many species of the genus. According to the review of Iwamoto (1978) C. fasciatus was found in samples from New Zealand after originally described for South West Africa and South America, and he also figured out that samples of $C$. fasciatus, taken at different parts of the oceans reveal morphometric differences. Thus, it's quite likely that our specimens from the southern part of Chile belong to C. cookianus, leading to the conclusion that this species may have a much wider range of geographical distribution than assumed.

Presence of larvae of unidentified Coelorinchus in zooplankton samples nearby from Penas Gulf (Balbotin, 2006) may suggest that the comparable shallow interior waters around the Campana Archipelago could represent a recruitment area for population of macrourids that live offshore since north of the Penas Gulf juveniles of $C$. fasciatus occur in the interior waters (Pequeño \& Riedemann, 2006), whereas the adults live on the upper slope off the continent (ZapataHernández et al. 2014).

Although we cannot confirm with exactitude that our specimens represent to $C$. cookianus or eventually a new species for science, the visual records from the Campana Archipelago is the first register of the genus Coelorinchus in the inner waters of the central region of the Chilean fjords and channels, and in a comparable shallow depth. Although underwater images sometimes do not allow exact identification at species level, it has been shown that visual observations by means of ROV and similar systems are useful tools to document marine biodiversity where traditional sampling is difficult as on seamounts and other the deep-sea environments (Easton et al. 2017). In fact, the yellow soldierfish Myripristis chryseres was detected by means of underwater video at Easter Island (Easton et al. 2018), and the first record of black corals attached underneath of rocks in shallow waters

Table 1. Geographic and bathymetric distribution ranges of macrourids of the genus Coelorinchus registered in Chilean waters, including the new record of Coelorinchus cf. cookianus.

\begin{tabular}{|c|c|c|c|c|c|c|c|c|c|c|c|c|}
\hline \multirow[b]{3}{*}{ Species } & \multicolumn{8}{|c|}{ Pacific } & \multicolumn{2}{|c|}{ Atlantic } & \multirow{2}{*}{\multicolumn{2}{|c|}{$\begin{array}{c}\text { Bathymetric } \\
\text { distribution (m.) }\end{array}$}} \\
\hline & \multicolumn{2}{|c|}{ SW } & \multicolumn{6}{|c|}{ SE } & \multirow{2}{*}{$\frac{\mathrm{SW}}{\mathrm{AR}}$} & \multirow{2}{*}{$\frac{\mathrm{W}}{\mathrm{AF}}$} & & \\
\hline & $\mathrm{AU}$ & $\mathrm{NZ}$ & $\mathrm{CA}$ & PA-PE & $\mathrm{JF}$ & $\mathrm{NC}$ & $\mathrm{S}(\mathrm{O})$ & $\mathrm{S}(\mathrm{I})$ & & & $\min$. & $\max$ \\
\hline C. aconcagua & & & & & $t^{3}$ & $+^{1}$ & & & $t^{3}$ & & $175^{3}$ & $600^{1}$ \\
\hline C. chilensis & & & & $+^{2}$ & $t^{3}$ & +1 & & & & & $200^{3}$ & $1480^{2}$ \\
\hline C. fasciatus & $t^{3}$ & $+^{2}$ & & & $t^{3}$ & $++^{1}$ & $+^{2}$ & $+^{2,3}$ & $+^{2}$ & $t^{2}$ & $73^{2}$ & $823^{2}$ \\
\hline C. scaphopsis & & & $+^{2}$ & & & & & & & & $183^{4}$ & $274^{4}$ \\
\hline C. canus & & & $+^{2}$ & $+^{2}$ & & & & & & & $70^{2}$ & $360^{2}$ \\
\hline C. innotabilis & $+^{4}$ & $+^{2,4}$ & & & & $t^{2}$ & & & & & & $1463^{2}$ \\
\hline C cookianus ${ }^{5}$ & & $+^{5}$ & & & & & & & & & $500^{5}$ & $800^{5}$ \\
\hline C. cf. cookianus* & & & & & & & & $t^{*}$ & & & $150^{*}$ & $150^{*}$ \\
\hline
\end{tabular}

+: record of the species in the area; ${ }^{1}$ Acuña et al. (2008) / ${ }^{2}$ Iwamoto (1978) / ${ }^{3}$ Reyes \& Hüne (2012) / ${ }^{4}$ Cohen et al. (1990) / ${ }^{5}$ McMillan et al. (2011) / "present study. Pacific: SW: Southwest Pacific; AU: Australia; NZ: New Zealand; SE: Southeast Pacific; CA: California; PA-PE: Panama - Peru; JF: Juan Fernandez Islands and seamounts; NC: Northern and Central Chile; S(O): southern Chile, south of $41^{\circ} \mathrm{S}$ (offshore); S(I): southern Chile, south of $41^{\circ} \mathrm{S}$ (internal waters); Atlantic: SW: Southwest; W: West; AR: Argentina: AF: Africa. The bathymetric distribution data indicate the minimum and maximum depths found for each species in the literature.. 
to the north of Coquimbo was also gained by using an ROV (Gorny et al. 2018).

Finally, the exploitation of shallow environments by deep-waters species for use as recruitment, feeding and nursery areas are issues that still need more attention and future surveys from channels and continental margins in the central Patagonia could provide new species or new records of species present in other regions. Given the ecological importance and the common concern about protecting and monitoring biodiversity, we consider any report about species distribution and local biodiversity as relevant to implement a successful management of natural resources and to develop conservation strategies.

\section{ACKNOWLEDGMENTS}

We wish to thank Captain Hector Diaz and his crew of the Exploradores Patagonia II for their ability to navigate through the October channel and to make the Katalalixar-II 2018 expedition a success. Also, thanks to the University of Magallanes for all logistic support. This expedition was financed by Oceana Chile.

\section{REFERENCES}

Acuña, E., Cortes, A., \& Cabrera, M.T. (2008). Grenadiers in the Demersal Community off Northern and Central Chile. American Fisheries Society Symposium, 63, 125135.

Balbotin, F. (2006). Ictioplancton de los canales y fiordos australes. In N. Silva \& S. Palma (Eds.), Avances en el conocimiento oceanográfico de las aguas interiores chilenas, Puerto Montt a cabo de Hornos (pp. 115120). Valparaíso: Comité Oceanográfico Nacional - Pontificia Universidad Católica de Valparaíso.

Bianchi, G., Carpenter, K. E., Roux, J.-P. M Molloy, F. J., Boyer, D., \& Boyer, H. J. (1999). FAO species identification guide for fishery purposes. Field guide to the living marine resources of Namibia. Rome: FAO.

Casassa, G., Rivera, A., Aniya, M., \& Naruse, R. (2002). Current knowledge of the southern Patagonia icefield. In G., Casassa,
F., Sepulveda, R., Sinclair (Eds.), The Patagonia Icefields (pp. 67-83). New York: Kluwer Plenum.

Cohen, D. M., Inada, T., Iwamoto, T., \& Scialabba, N. (1990). FAO species catalogue. Vol. 10. Gadiform fishes of the world (Order Gadiformes). An annotated and illustrated catalogue of cods, hakes, grenadiers and other gadiform fishes known to date. FAO Fisheries Synopsis. 125 (10). Rome: FAO. 442 p.

Easton, E. E., Sellanes J., Gaymer, C. F., Morales, N., Gorny, M., \& Berkenpas, E. (2017). Diversity of deep-sea fishes of the Easter Island Ecoregion. Deep Sea Research Part II: Topical Studies in Oceanography, 137, 78-88.

Easton, E. E., Sellanes J., \& Gorny M. (2018). First record of the yellowfin soldierfish, Myripristis chryseres Jordan and Evermann 1903 (Beryciformes: Holocentridae), in the Easter Island Ecoregion. Pacific Science, 72(1), 143-148.

Friedlander, A. M., Ballesteros, E., Beets, J., Berkenpas, E., Gaymer, C. F., Gorny, M., \& Sala, E. (2013). Effects of isolation and fishing on the marine ecosystems of Easter Island and Salas y Gómez, Chile. Aquatic Conservation: Marine and Freshwater Ecosystems, 23(4), 515-531.

Eschmeyer, W. N., Fricke, R., \& van der Laan, R. (2018). Catalog of fishes: genera, species; references.http://researcharchive. calacademy.org/research/ichthyology/ catalog/fishcatmain.asp. Electronic version accessed 17 August 2018.

Gorny, M., Easton E. E., \& Sellanes, J. (2018). First record of black corals (Antipatharia) in shallow coastal waters of northern Chile by means of underwater video. Latin American Journal of Aquatic Research, 46(2), 457460.

Iwamoto, T. (1978). Eastern Pacific macrourids of the genus Coelorhinchus Giorna (Pisces: Gadiformes), with description of a new species from Chile. Proceeding of the California Academy of Science, 41(12), 307-337.

McCann, C., \& McKnight, D. G. (1980). The 
marine fauna of New Zealand: macrourid fishes (Pisces: Gadida). New Zealand Oceanographic Institute Memoir, 61, 1-91.

McMillan, P. J., \& Paulin, C. D. (1993). Description of nine new species of rattails of the genus Caelorinchus (Pisces, Macrouridae) from New Zealand. Copeia, 3, 819-840.

McMillan, P J., Francis, M. P., James, G. D., Paul, L. J., Marriott, J. P., Mackay, E.,... \& Wei, F. (2011). New Zealand fishes. Volume 1: A field guide to less common species caught by bottom and midwater fishing. New Zealand Aquatic Environment and Biodiversity Report, 68, 331 pp.

Mutschke, E., \& Gorny, M. (1999). The benthic decapod fauna in the channels and fjords along the South Patagonian Ice field, Southern Chile. Scientia Marina, 63(1), 315-319
Pequeño, G., \& Riedemann, A. (2006). Peces bentónicos capturados en el crucero cimar 8 fiordos, en los canales de aysén (XI región, Chile). Ciencia y Tecnología del Mar, 29(1), 163-172

Priede, I. (2017). The Deep-sea fish faunas. In I. Priede (Ed.). The deep-sea fihes: Biology, diversity, ecology and fisheries (504 pp.). Cambridge:. Cambridge University Press.

Reyes, P. L., \& Hüne M. B. (2012). Peces del Sur de Chile. Santiago de Chile: Editorial Ocho Libros.

Zapata-Hernández, G., Sellanes, J., Thurber, A. R., \& Levin, L. A. (2014). Trophic structure of the bathyal benthos at an area with evidence of methane seep activity off southern Chile $\left(\sim 45^{\circ} \mathrm{S}\right)$. Journal of the Marine Biological Association of the United Kingdom, 94(4), 659-669. 